\title{
Tinidazole in the treatment of bacterial vaginosis
}

This article was published in the following Dove Press journal:

International Journal of Women's Health

23 June 2009

Number of times this article has been viewed

\author{
Nicola R Armstrong' \\ Janet D Wilson² \\ 'Department of Infectious Diseases \\ and Sexual Health, Trinity Centre, \\ Bradford, UK; ${ }^{2}$ The Centre \\ for Sexual Health, The General \\ Infirmary at Leeds, Leeds, UK
}

\begin{abstract}
Bacterial vaginosis (BV) is the commonest cause of vaginal discharge in women of childbearing age. Oral metronidazole has long been established as an effective therapy in the treatment of BV. However, adverse effects due to metronidazole are frequent and this may lead to problems with adherence to a 7-day course of treatment and subsequently result in treatment failure. Oral tinidazole has been used to treat bacterial vaginosis for over 25 years but in a number of different dosage regimens. Placebo controlled trials have consistently shown increases in cure rate with tinidazole. Longer courses of treatment (eg, $1 \mathrm{~g}$ daily for 5 days) appear to be more effective than a $2 \mathrm{~g}$ oral single dose. Comparative studies suggest that oral tinidazole is equivalent to oral metronidazole, intravaginal clindamycin cream, and intravaginal metronidazole tablets, in efficacy in treating BV. However, tinidazole has a more favorable side effect profile than oral metronidazole notably with better gastrointestinal tolerability and less metallic taste. Bacterial vaginosis is associated with high rates of recurrence and appropriate management of such recurrences can prove difficult. Recurrent BV has been linked with persistence of Gardnerella vaginalis after treatment; however the clinical implications of the possible greater activity of tinidazole against $G$. vaginalis are not yet clear. Repeated courses of oral metronidazole may be poorly tolerated and an alternative but equally effective treatment that is better tolerated may be preferable. In comparison to oral metronidazole, cost is clearly an issue as oral metronidazole is considerably cheaper and available in generic form. However where avoidance of oral metronidazole is necessary because of side effects, oral tinidazole is a cost-effective alternative.
\end{abstract}

Keywords: bacterial vaginosis, tinidazole, metronidazole, Gardnerella vaginalis

\section{Introduction}

Bacterial vaginosis (BV) is the commonest cause of vaginal discharge in women of childbearing age. It is characterized by a thin homogenous white discharge, a vaginal $\mathrm{pH}$ of greater than 4.5, a positive amine test and the presence of clue cells microscopically. There is a change from the normal lactobacilli (LB) dominant vaginal flora, with hydrogen peroxide production, to flora with greatly reduced numbers of LB and an increase in the concentration and prevalence of organisms including Gardnerella vaginalis, Mycoplasma hominis and anaerobic bacteria such as peptostretococci, Prevotella spp., and Mobiluncus spp. ${ }^{1}$ Recently Atopobium vaginae, and some nonculturable species identified by molecular analysis (named BV associated bacteria [BVAB]), have also been found in association with BV., ${ }^{2,3}$

The diagnosis of bacterial vaginosis can be made using the Amsel's clinical criteria. ${ }^{4}$ Three of the following should be present: thin homogenous white discharge, vaginal 
$\mathrm{pH}$ greater than 4.5, amine odor after adding $10 \%$ potassium hydroxide to vaginal fluid, and clue cells on microscopy (at least 1 in 5 vaginal epithelial cells). Alternatively a vaginal smear can be Gram-stained and scored microscopically as according to Nugent. ${ }^{5}$ The scoring is between 0 and 10 based on the relative quantities of various bacteria. Scores of 7 to 10 are consistent with BV, 4 to 6 indicate intermediate flora and 0 to 3 are normal flora.

The pathogenesis of BV is not yet clearly understood. $\mathrm{BV}$ has been associated with a number of complications including risk of late miscarriage and preterm birth, ${ }^{6}$ postoperative infections including postabortion-PID, posthysterectomy cuff cellulitis and postCesarean endometritis, ${ }^{7}$ and possibly pelvic inflammatory disease (PID) ${ }^{8}$ It has also been associated with an increased risk of acquiring HIV-1 infection. ${ }^{9,10}$

Oral metronidazole has long been established as an effective therapy in the treatment of BV. Intravaginal preparations of metronidazole and clindamycin have also been widely used. In 1999 Joesoef et al updated their previous publication which had reviewed treatment options for BV. ${ }^{11,12}$ The additional published studies on the treatment of bacterial vaginosis from 1993 through to 1996 were reviewed. Their first-line recommended treatments in nonpregnant women were oral metronidazole $500 \mathrm{mg}$ twice daily for 7 days, or clindamycin vaginal cream $2 \%$ once daily for 7 days, or metronidazole vaginal gel $0.75 \%$ twice daily for 5 days. There were no statistically significant differences in cumulative cure rates between these treatments. Their previous paper had identified that the 7-day regimen of oral metronidazole was more efficacious than the single dose regimen of $2 \mathrm{~g}$ of metronidazole (the cumulative cure rates 3 to 4 weeks after completion of treatment were $82 \%$ vs $62 \%) .{ }^{11}$

However, adverse effects due to metronidazole are frequent, ${ }^{13}$ and this may lead to problems with adherence to a 7-day course of treatment and subsequently result in treatment failure. Consequently, other drugs of the nitroimidazole class have been explored as alternatives to metronidazole for the treatment of BV.

Tinidazole, 1-[2-(ethylsulfonyl)ethyl]-2-methyl-5nitroimidazole, was first introduced into clinical medicine in 1967 for the treatment of Trichomonas vaginalis infections. ${ }^{14}$ It has subsequently been used for the treatment of other protazoal infections including giardiasis and amoebiasis, in the eradication of Helicobacter pylori infection, and in anaerobic infections such as intraperitoneal infections, postoperative wound infections, skin and soft tissue infections and gynecological infections including BV.
Here we review both the pharmacological profile of tinidazole and the evidence for its efficacy in the treatment of BV.

\section{Mechanism of action, pharmacokinetics and metabolism}

Tinidazole is a prodrug that is converted to cytotoxic forms in vivo. It has a low molecular weight and penetrates the cell membrane of both aerobic and anaerobic microorganisms. After diffusing into the cells of susceptible organisms, tinidazole is reduced at its nitro group to short lived toxic radicals by a ferridoxin-mediated transport system. It is thought that these toxic intermediates bind to DNA resulting in DNA damage which ultimately leads to cell death. ${ }^{15}$ Most aerobic bacteria are unable to generate the toxic radicals and are thus not susceptible to tinidazole.

A pharmacokinetic comparison of oral tinidazole $500 \mathrm{mg}$ and oral metronidazole $500 \mathrm{mg}$ showed tinidazole to a have a significantly higher $\mathrm{C}_{\max }$, area under the curve, and longer half-life. ${ }^{16}$ Both drugs achieve good tissue levels in the female reproductive tract at $70 \%$ to $100 \%$ of those of the simultaneous serum levels. However, the steady-state serum concentration of tinidazole following oral administration was higher than that of metronidazole. ${ }^{17}$ The half-life of tinidazole is 12.7 hours and the antimicrobial plasma concentrations maintained in the tissues are sufficient to permit once daily dosing. The pharmacokinetic properties are similar after oral doses of $2000 \mathrm{mg}$ and intravenous doses of $800 \mathrm{mg}$ and $1600 \mathrm{mg}$. It is minimally bound to plasma protein (12\%) and is widely distributed in all body tissues.

Elimination is primarily by hepatic metabolism (approximately $63 \%$ ). Due to lack of data, use of tinidazole in patients with severe hepatic impairment is not recommended. No adjustment of the tinidazole dosage appears to be necessary based on renal function. ${ }^{18}$

\section{In vitro activity}

Tinidazole is active against anaerobic protozoa including T. vaginalis, $E$ histolytica and $G$ lamblia. It also has in vitro activity against most anaerobic bacteria including Bacteriodes, Fusobacterium and Clostridium spp. ${ }^{18}$ Two comparative in vitro studies showed minor enhanced in vitro activity against $G$. vaginalis with tinidazole compared to metronidazole. ${ }^{19,20}$ More recently, antimicrobial susceptibility testing to metronidazole and tinidazole was performed on 470 vaginal isolates from women with bacterial vaginosis. ${ }^{21}$ The overall spectrum of activity against the BV-associated bacteria was very similar. Lactobacillus isolates were the least susceptible to tinidazole and metronidazole with $96 \%$ 
and $100 \%$ of Lactobacillus isolates showing resistance. This was expected as facultative organisms are generally not inhibited by nitroimidazoles because the reduction of the nitro group is dependent upon the absence of oxygen. Of the G. vaginalis isolates $54 \%$ and $68 \%$ were resistant to tinidazole and metronidazole respectively. $15 \%$ of the $G$ vaginalis isolates were resistant to metronidazole but susceptible to tinidazole, whereas only one isolate was susceptible to metronidazole and resistant to tinidazole $(P=0.001)$. Tinidazole therefore shows activity against anaerobes similar to that of metronidazole with slightly greater activity against G. vaginalis. Mobiluncus spp. are resistant to both metronidazole and tinidazole with similar MICs. ${ }^{22}$ Atopobium vaginae also appears to be highly resistant to metronidazole, but susceptibility testing to tinidazole was not performed. ${ }^{2}$ There are no efficacy data against the newly identified nonculturable bacteria associated with BV.

\section{Studies of tinidazole and BV}

Oral tinidazole has been used to treat bacterial vaginosis for over 25 years but in a number of different dosage regimens. There have been a number of published clinical studies but unfortunately there are several problems in trying to compare and evaluate these trials. Many were carried out prior to the universally recognized diagnostic clinical criteria of $\mathrm{Amsel}^{4}$ and the Nugent Gram stain score ${ }^{5}$ and before the use of the term 'bacterial vaginosis' was introduced when the condition was known as non specific vaginitis. Furthermore there are differences in the dosing and duration of tinidazole used, ranging from 1 to $2 \mathrm{~g}$ daily for 1 to 5 days, and also in the comparator drug.

Comparison of treatment trials for $\mathrm{BV}$ has been recognized as being complex. In 1992 Larsson reviewed treatments of bacterial vaginosis. ${ }^{23} \mathrm{He}$ cited the following differences between treatment studies: the criteria used for the diagnosis of BV vary; different exclusion criteria are used; the definition of cure varies; the timing of treatment evaluation varies; and some studies are double-blind placebo controlled trials whereas others are open trials. ${ }^{23}$ In order to try to overcome these differences, in 1998, the FDA issued a draft guidance document entitled "Bacterial Vaginosis Developing Antimicrobial Drugs for Treatment". ${ }^{24}$ This called for investigators to define BV in study participants as the presence of all four of Amsel's criteria plus a Nugent score of 7 to 10 , and to perform the examination for evaluation of therapeutic response at 21 to 30 days after the first few days of treatment. It recommended that cure should be defined as absence of all four Amsel's criteria plus a Nugent score of 0 to 3 . While these recommendations may ensure uniformity amongst trial evaluations, such a strict definition of cure may not necessarily identify differences between treatment efficacies. An example of variation in treatment results using the different methods of evaluation was shown in a comparison of two intravaginal metronidazole regimens for the treatment of $\mathrm{BV} .{ }^{25}$ The authors observed a significant difference between the two regimens at follow up when BV was defined by the presence of at least three of four Amsel's criteria, or a Nugent score of 7 to 10, or both. However, no significant difference in rates of cure was found using the 1998 FDA draft guidance definition of cure. ${ }^{25}$ Only the most recently published study comparing two different doses of tinidazole to treat $\mathrm{BV}$ has used the FDA definition of cure. ${ }^{26}$

Although comparison between different treatment studies is difficult, placebo controlled trials have consistently shown increases in cure rate with tinidazole (see Table 1). ${ }^{26-30}$ The cure rates with tinidazole ranged from $46 \%$ to $71 \%$ for tinidazole $2 \mathrm{~g}$ oral single dose, $74 \%$ for $2 \mathrm{~g}$ daily for 2 days and $91 \%$ for the $1 \mathrm{~g}$ daily for 5 days dose. ${ }^{27-30}$ Comparative studies suggest that oral tinidazole is equivalent to oral metronidazole, ${ }^{20,31-35}$ intravaginal clindamycin cream, ${ }^{33,35}$ and intravaginal metronidazole tablets, ${ }^{36}$ in efficacy in treating BV. There are no data comparing oral tinidazole with intravaginal metronidazole gel.

In 2007 Nailor and Sobel reviewed 21 clinical efficacy studies evaluating tinidazole for bacterial vaginosis. ${ }^{37}$ They concluded that compared with placebo, tinidazole in all studied regimens consistently demonstrated at least short term efficacy in eradicating signs and symptoms of BV. Tinidazole $2 \mathrm{~g}$ /day (single daily dose) for 2 days appeared more effective than a single tinidazole $2 \mathrm{~g}$ dose (1 day dose). A lower daily dose (500 mg twice daily or $1 \mathrm{~g}$ once daily) taken for a longer period, for example 5 days, was also highly effective. ${ }^{37}$ Following that review, Livengood et $\mathrm{al}^{26}$ published the results of a randomized controlled trial assessing the effectiveness of tinidazole orally $1 \mathrm{~g}$ once daily for 5 days and $2 \mathrm{~g}$ once daily for 2 days, compared with placebo, in the treatment of bacterial vaginosis. Follow up was at 21 to 30 days after treatment, using the strict FDA recommended criteria to define cure. Cure rates were $36.8 \%$ for the $1 \mathrm{~g}$ daily for 5 days regimen, $27.4 \%$ for the $2 \mathrm{~g}$ daily for 2 days regimen and $5.1 \%$ for the placebo group. They concluded that both regimens gave significantly higher cure rates than placebo and are an effective treatment for BV. The $1 \mathrm{~g}$ once daily for 5 days regimen showed trends toward better efficacy and 
Table I Clinical studies evaluation efficacy of tinidazole for bacterial vaginosis

\begin{tabular}{|c|c|c|c|c|c|c|}
\hline \multirow[t]{2}{*}{ Reference } & \multirow[t]{2}{*}{ No. in study } & \multirow[t]{2}{*}{ Tinidazole cure rate $(\%)$} & \multicolumn{3}{|c|}{ Comparators, doses and cure rates (\%) } & \multirow[t]{2}{*}{ Ref } \\
\hline & & & Metronidazole & Placebo & Other & \\
\hline \multicolumn{7}{|l|}{$2 \mathrm{~g}$ (and I $\mathrm{g}$ bid) studies } \\
\hline Paavonen $1983^{27}$ & 33 & 71 & & 38 & & 27 \\
\hline van der Meiden $1983^{29}$ & 26 & 46 & & 8 & & 29 \\
\hline Ekgren $1988^{30}$ & 247 & 51 & & 4 & 74 (tinidazole $2 \mathrm{~g} \times 2$ days) & 30 \\
\hline Mohanty $1987^{20}$ & 280 & 92 & $79(2 \mathrm{~g})$ & & 88 (nimorazole) & 20 \\
\hline Milani $2003^{35}$ & 89 & 88 & $73(2 \mathrm{~g})$ & & & 35 \\
\hline Sanz-Sanz 1985'1 (I g bid) & 80 & 65 & 74 (500 mg bid $\times 7$ days $)$ & & & 31 \\
\hline Buranawarodomkul $1990^{32}$ & 100 & 86 & $92(500 \mathrm{mg}$ bid $\times 7$ days $)$ & & & 32 \\
\hline Sanz-Sanz $1996^{33}$ & 230 & 75 & 80 (500 mg bid $\times 7$ days $)$ & & $\begin{array}{l}85 \text { (ciprofloxacin } \\
500 \mathrm{mg} \text { bid } \times 3 \text { days) } \\
85 \text { (clindamycin vaginal } \\
\text { cream } 2 \% \times 7 \text { days) }\end{array}$ & 33 \\
\hline Milani $2003^{34}$ & 64 & 94 & & & $\begin{array}{l}77 \text { (clindamycin vaginal } \\
\text { cream } 2 \% \times 7 \text { days) }\end{array}$ & 34 \\
\hline Schindler $\left.199\right|^{36}$ & 75 & 84 & $\begin{array}{l}82 \text { ( } 400 \mathrm{mg} \text { bid } \times 5 \text { days } \\
\text { intravaginal tablet })\end{array}$ & & & 36 \\
\hline \multicolumn{7}{|c|}{$2 \mathrm{~g} \times 2$-day or $2 \mathrm{~g} \times 3$-day studies (or $1 \mathrm{~g}$ bid $\times 2$ or 3 days) } \\
\hline Sanz-Sanz $1985^{31}$ & 60 & 50 (I g bid $\times 2$ days $)$ & & & $\begin{array}{l}63 \text { (ornidazole } \\
\text { I g bid } \times 2 \text { days) }\end{array}$ & 31 \\
\hline Ekgren $1988^{30}$ & 247 & 74 ( $2 \mathrm{~g} \times 2$ days $)$ & & 4 & 51 (tinidazole $2 \mathrm{~g}$ ) & 30 \\
\hline Livengood $2007^{26}$ & 235 & $27.4(2 \mathrm{~g} \times 2$ days $)$ & & 5.1 & & 26 \\
\hline \multicolumn{7}{|l|}{ I g $\times$ 5-day studies } \\
\hline $\begin{array}{l}\text { Piot } 1983^{28} \\
(500 \mathrm{mg} \text { bid } \times 5 \text { days })\end{array}$ & 57 & 91 & & 40 & $\begin{array}{l}44 \text { (intravaginal, } \\
\text { sulfa bid } \times 7 \text { days) }\end{array}$ & 28 \\
\hline Livengood $2007^{26}$ & 235 & 36.8 & & 5.1 & & 26 \\
\hline
\end{tabular}

tolerability than the $2 \mathrm{~g}$ once daily for 2 days regimen but this was not statistically significant. ${ }^{26}$

Whether or not tinidazole has better efficacy than metronidazole is currently impossible to say. When the same drug dose and duration have been compared (ie, $2 \mathrm{~g}$ single day dose) tinidazole has had higher cure rates than metronidazole. ${ }^{20,35}$ However, it is now recognized that single dose oral therapy is not as effective as a longer course and metronidazole $2 \mathrm{~g}$ single dose is no longer recommended as first-line therapy for BV. ${ }^{11,38}$ There has been no published head-to-head comparison of the more effective oral metronidazole regimen (500 mg twice daily for 7 days) with the more effective tinidazole regimen ( $1 \mathrm{~g}$ daily for 5 days). Such a study is needed to clarify if there are any differences in cure rates of BV between the two treatments.

Recurrences of bacterial vaginosis are frequent and appropriate management can prove difficult. ${ }^{1}$ Persistence of G. vaginalis ${ }^{39}$ Atopodium vaginae, ${ }^{39}$ Mobiluncus curtisii, ${ }^{40}$ and the $\mathrm{BVAB}^{41}$ after treatment has been linked with recurrences of BV. Both metronidazole and tinidazole appear to be ineffective against $M$. curtisii, however the clinical implications of the possible greater activity of tinidazole against $G$. vaginalis are not yet clear. ${ }^{21}$ Repeated courses of oral metronidazole may be poorly tolerated and an alternative equally effective treatment that is better tolerated may be preferable.

\section{Current recommended use of tinidazole}

The 2006 UK National Guidelines for the management of bacterial vaginosis currently recommend oral metronidazole as first-line treatment with tinidazole $2 \mathrm{~g}$ single oral dose as an alternative. ${ }^{42}$ The 2004 Australasian College of Sexual Health Physicians Clinical Guidelines for the management of sexually transmissible infections among priority populations list tinidazole $2 \mathrm{~g}$ single oral dose for the treatment of bacterial vaginosis but caution that the cure rate may be lower than a longer course of treatment. ${ }^{43}$ 
The 2001 European, ${ }^{44}$ the 2003 WHO, ${ }^{45}$ the 2006 US, ${ }^{38}$ and the 2008 Canadian ${ }^{46}$ guidelines do not include tinidazole as a preferred or alternative option in the treatment of bacterial vaginosis. Of note is that the US Food and Drug Administration (FDA) only approved tinidazole for the treatment of bacterial vaginosis in May 2007 based on the results of the Livengood study. ${ }^{26}$ This approval was after the publication of the current 2006 sexually transmitted diseases treatment guidelines.

\section{Safety and tolerability}

There is substantial information regarding the tolerability of tinidazole and its safety profile. It seems to be free from clinical toxicity following standard oral and intravenous doses. Apte and Packard evaluated the safety of tinidazole in 1517 adult and pediatric patients. ${ }^{47} \mathrm{Of}$ these, 143 patients $(9.4 \%)$ experienced one or more adverse event. The most frequently encountered adverse events were nausea (3.6\%), abdominal discomfort (2.4\%), vomiting $(1.7 \%)$, anorexia (1.3\%), constipation $(1.2 \%)$, headache $(0.9 \%)$, and a dry mouth $(0.6 \%) .{ }^{47}$ An analysis of the results of 5 randomized controlled trials comparing tinidazole with metronidazole for the treatment of 99 patients with confirmed amoebic liver abscess reported gastrointestinal adverse events in $6 \%$ of patients receiving tinidazole and $41 \%$ of patients receiving metronidazole. ${ }^{48}$ Patients who received metronidazole experienced significantly more nausea $(36.7 \%$ with metronidazole versus $6.0 \%$ with tinidazole; $P \leq 0.01)$, anorexia $(28.6 \%$ versus $4.0 \% ; P \leq 0.01)$, vomiting $(24.4 \%$ versus $0 \%)$ and metallic taste $(18.4 \%$ versus $0 \%) .^{48}$

Adverse events associated with tinidazole are usually mild and self-limiting. Hypersensitivity reactions have however been reported, presenting as angioedema, periorbital and laryngeal edema, bronchospasm, dyspnea, fixed drug eruptions and generalized urticaria. There have been reports of peripheral neuropathy and convulsions associated with metronidazole use, so it is recommended that tinidazole should be used with caution in patients with central nervous system syndromes and abnormalities. ${ }^{15}$

Tinidazole crosses the placental barrier. Since the effects of compounds of this class on fetal development are unknown, the manufacturers recommend avoidance during the first trimester. There is no evidence that it is harmful during the latter stages of pregnancy, but its use during the second and third trimesters requires the potential benefits be weighed against possible hazards to mother or fetus (Summary of Product Characteristics [SPC] Fasigyn ${ }^{\circledR}$; Pfizer Ltd, Ramsgate Road, Sandwich, Kent, UK).

\section{Interactions}

Like metronidazole, concurrent use of tinidazole with alcohol may produce a disulfram-like reaction and should be avoided. Drugs of similar chemical structure have been shown to potentiate the effects of oral anticoagulants and it is advised that prothombin time be monitored closely (SPC). Co-administration of lithium and metronidazole may increase the risk of lithium toxicity. It is not known if this interaction occurs with other nitroimidazoles but close monitoring of lithium levels would be advised when given with tinidazole.

\section{Cost}

Oral metronidazole is the least expensive of all established treatments for bacterial vaginosis. The British National Formulary quotes the current UK price ${ }^{49}$ as $£ 1.29$ for a 21-tablet pack of $400 \mathrm{mg}$ tablets. Metronidazole $0.75 \%$ intravaginal gel $40 \mathrm{~g}$ pack costs $£ 4.31$ compared to $£ 10.86$ for clindamycin $2 \%$ intravaginal cream $40 \mathrm{~g}$ pack. Oral tinidazole has a price of $£ 13.80$ for a 20 -tablet pack of $500 \mathrm{mg}$ tablets meaning a $2 \mathrm{~g}$ single dose costs $£ 2.76$ and $1 \mathrm{~g}$ daily for 5 days regimen costs $£ 6.90$ (see Table 2). Therefore, if an alternative to oral metronidazole is required, oral tinidazole compares favorably in terms of cost with both metronidazole and clindamycin intravaginal preparations.

Table 2 Approximate costs of treatment regimens for bacterial vaginosis from British National Formulary March 200949

\begin{tabular}{lll}
\hline Drug & Dose and duration & Cost $(\boldsymbol{(})$ \\
\hline Oral metronidazole & $400 \mathrm{mg} / 500 \mathrm{mg}$ twice daily for 7 days & 0.86 \\
Oral metronidazole & $2 \mathrm{~g}$ single dose & $0.3 \mathrm{I}$ \\
Metronidazole $0.75 \%$ intravaginal gel, $40 \mathrm{~g}$ pack & $5 \mathrm{~g}$ applicator per night for 5 nights & $4.3 \mathrm{I}$ \\
Clindamycin 2\% intravaginal cream, $40 \mathrm{~g}$ pack & $5 \mathrm{~g}$ applicator per night for 7 nights & 10.86 \\
Oral tinidazole & $1 \mathrm{~g}$ daily for 5 days & 6.90 \\
Oral tinidazole & $2 \mathrm{~g}$ single dose & 2.76 \\
\hline
\end{tabular}




\section{Conclusion}

Tinidazole shows proven efficacy in the treatment of BV. The cure rates are comparable to those of metronidazole, but clinical superiority has not been demonstrated. However, tinidazole has a more favorable side effect profile, notably with better gastrointestinal tolerability and less metallic taste, both of which are often implicated in poor adherence to metronidazole therapy. Comparative studies suggest that oral tinidazole is equivalent to intravaginal clindamycin cream and intravaginal metronidazole tablets in efficacy in the treatment of BV. The optimal dose and duration of tinidazole has not been established but it appears that longer courses are better than single day therapy.

Bacterial vaginosis is associated with high rates of recurrence and appropriate management of such recurrences can prove difficult. Recurrent BV has been linked with persistence of G. vaginalis after treatment; however the clinical implications of the possible greater activity of tinidazole against $G$. vaginalis are not yet clear. Repeated courses of oral metronidazole may be poorly tolerated and an alternative but equally effective treatment that is better tolerated may be preferable.

In comparison to oral metronidazole, cost is clearly an issue as metronidazole is considerably cheaper and available in generic form. However where avoidance of oral metronidazole is necessary because of side effects, oral tinidazole is a cost-effective alternative.

\section{Disclosures}

The authors declare no conflicts of interest.

\section{References}

1. Wilson J. Managing recurrent bacterial vaginosis. Sex Transm Infect. 2004;80:8-11.

2. Ferris MJ, Masztal A, Aldridge KE, Fortenberry D, Fidel Jr PL, Martin DH. Association of Atopobium vaginae, a recently described metronidazole resistant anaerobe, with bacterial vaginosis. BMC Infect Dis. 2004;4:5.

3. Fredricks D, Fiedler BS, Marazzo JM. Molecular identification of bacteria associated with bacterial vaginosis. N Eng J Med. 2005;353:1899-1911.

4. Amsel R, Totten PA, Spiegal CA, et al. Nonspecific vaginitis: diagnostic criteria and microbial and epidemiologic associations. Am J Med. 1983;74:14-22.

5. Nugent RP, Krohn MA, Hillier SL. Reliability of diagnosing vaginosis is improved by a standardized method of Gram stain interpretation. J Clin Microbiol. 1991;29:297-301.

6. Leitich H, Bodner-Adler B, Brunbauer M, Kaider A, Egarter C, Hussein P. Bacterial vaginosis as a risk factor for preterm delivery: A meta-analysis. Am J Obstet Gynecol. 2003:189:139-147.

7. Soper DE. Bacterial vaginosis and postoperative infections. Am JObstet Gynaecol. 1993;169:467-469.

8. Ness RB, Kip KE, Hillier SL, Soper DE, Stamm CA, Sweet RL, et al. A cluster analysis of bacterial vaginosis-associated microflora and pelvic inflammatory disease. Am J Epidemiol. 2005;162:585-590.
9. Taha TE, Hoover DR, Dallabetta GA, et al. Bacterial vaginosis and disturbances in vaginal flora: association with increased acquisition of HIV. AIDS. 1998;12:1699-1706.

10. Martin H, Nyange PM, Richardson BA, et al. Vaginal lactobacilli, microbial flora, and risk of human immunodeficiency virus type 1 and sexually transmitted disease acquisition. J Infect Dis. 1999;180: 1863-1868

11. Joesoef MR, Schmid GP. Bacterial vaginosis: review of treatment options and potential clinical indications for therapy. Clin Infect Diseases. 1995:20(Suppl 1):s72-s79.

12. Joesoef MR, Schmid GP, Hillier SL. Bacterial vaginosis: review of treatment options and potential clinical indications for therapy. Clin Infect Dis. 1999:28(suppl 1):s57-s65.

13. Brandt M, Abels C, May T, Lohmann K, Schmidts-Winkler I, Hoyme UB. Intravaginally applied metronidazole is as effective as orally applied in the treatment of bacterial vaginosis, but exhibits significantly less side effects. Eur J Obstet Gynecol Reprod Biol. 2008;141:158-162.

14. Miller MW, Howes HL, English AR. Tinidazole, a potent new antiprotazoal agent. Antimicrob Agents Chemother. 1969;1:257-260.

15. Fung HB, Doan T. Tinidazole: a nitroimidazole antiprotazoal agent. Clin Ther. 2005;27:1859-1884.

16. Mattila J, Mannisto PT, Mantyla R, Nykanen S, Lamminsivu U. Comparative pharmacokinetics of metronidazole and tinidazole as influenced by administration route. Antimicrob Agents Chemother. 1983;23:721-725.

17. Mannisto P, Karhunen M, Mattila J, et al. Concentrations of metronidazole and tinidazole in female reproductive organs after a single intravenous infusion and after repeated oral administration. Infection. 1984;12:197-201

18. Nord CE, Kager L. Tinidazole-microbiology, pharmacology and efficacy in anaerobic infections. Infection. 1983:11;54-60.

19. Carmona O, Silva H, Acosta H. Vaginitis due to Gardenerella vaginalis: treatment with tinidazole. Curr Ther Res. 1983;22:898-904.

20. Mohanty KC, Deighton R. Comparison of $2 \mathrm{~g}$ single dose of metronidazole, nimorazole and tinidazole in the treatment of vaginitis associated with Gardnerella vaginalis. J Antimicrob Chemother. 1987;19:393-399.

21. Austin MN, Meyn LA, Hillier SL. Susceptibility of vaginal bacteria to metronidazole and tinidazole. Anaerobe. 2006;12:227-230.

22. Spiegel CA. Susceptibility of Mobiluncus species to 23 antimicrobial agents and 15 other compounds. Antimicrob Agents Chemother. 1987;31:249-252.

23. Larsson PG. Treatment of bacterial vaginosis. Int J STD AIDS. 1992;3:239-247.

24. US Department of Health and Human Services, Food and Drug Administration, Centre for Drug Evaluation and Research (CDER). Guidance for industry: bacterial vaginosis - developing antimicrobial drugs for treatment. Draft guidance. July 1998. Available at: www.fda. gov/cder/guidance/2572dft.pdf.

25. Thomas KK, Sanchez S, Garcia PJ, et al. Why do different criteria for 'cure' yield different conclusions in comparing two treatments for bacterial vaginosis? Sex Transm Dis. 2005;32:526-530.

26. Livengood $\mathrm{CH}$, Ferris DG, Wiesenfeld $\mathrm{HC}$, et al. Effectiveness of two tinidazole regimens in treatment of bacterial vaginosis: a randomised controlled trial. Obstet Gynaecol. 2007;110:302-309.

27. Paavonen J, Vesterinen E, Purola E, et al. Single dose of tinidazole in the treatment of vaginal discharge. Scand J Urol Nephrol Suppl. 1984;86:237-240.

28. Piot P, Van Dyck E, Godts P, Vanderheyden J. A placebo-controlled, double-blind comparison of tinidazole and triple sulfonamide cream for the treatment of nonspecific vaginitis. Am J Obstet Gynaecol. 1983;147:85-89.

29. van der Meijden WI. Treatment of nonspecific vaginitis with a single dose of tinidazole. Scand J Infect Dis Suppl. 1983;40:85-89.

30. Ekgren J, Norling BK, Degre M, Midtvedt T. Comparison of tinidazole given as a single dose and on 2 consecutive days for the treatment of nonspecific bacterial vaginosis. Gynaecol Obstet Invest. 1988;26:313-317. 
31. Sanz-Sanz F, Hernanz AD, Sancher EA, Alvarez CG, Muelas M, Rodriguez-Noriega A. Controlled comparative study of metronidazole (Flagyl) versus tinidazole (Tricolan) in the treatment of nonspecific vaginitis (vaginitis due to Gardnerella vaginalis). Rev Gynaecol Obstet. 1985;44:717-720.

32. Buranawarodomkul P, Chandeying V, Sutthijumroon S. Seven day metronidazole versus single dose tinidazole as therapy for nonspecific vaginitis. J Med Assoc Thai. 1990;73:283-287.

33. Sanz-Sanz F, Arreaza L, Vidriales I, Miranda P, Grande J, Valle R. Concerning the different therapeutic options for bacterial vaginosis. Progresso Obstet Ginecol. 1996;39:669-674.

34. Milani M, Barcellona E, Agnello A. Efficacy of the combination of $2 \mathrm{~g}$ oral tinidazole and acidic buffering vaginal gel in comparison with vaginal clindamycin alone in bacterial vaginosis: a randomised, investigator-blinded controlled trial. Eur J Obstet Gynaecol Reprod Biol. 2003;109:67-71.

35. Milani M, Baldoni A, Guerro B, Spinillo A. The "talent" multicenter trial: efficacy of tinidazole, metronidazole, and tinidazole + acidic gel in the treatment of B.vaginosis. Abstracts of the 86th World Congress for Infectious and Immunological Diseases in Obstetrics and Gynaecology. Venice, Italy, November 2003.

36. Schindler EM, Thamm H, Ansmann EB, Sarnow E, Schindler AE. Treatment of bacterial vaginitis. Multicenter, randomised, open study with tinidazole in comparison with metronidazole. Fortschr Med. 1991;109(5):138-140.

37. Nailor MD, Sobel JD. Tindazole for bacterial vaginosis. Expert Opin Investig Drugs. 2007;16:743-751.

38. CDC. Sexually transmitted diseases treatment guidelines MMWR 2006 RR-11. Available from http://www.cdc.gov/std/treatment/2006/ vaginal-discharge.htm\#vagdis2.

39. Bradshaw CS, Tabrizi SN, Fairley CK, Morton AN, Rudland E, Garland SM. The association of Atopobium vaginae and Gardnerella vaginalis with bacterial vaginosis and recurrence after oral metronidazole therapy. J Infect Dis. 2006;194:828-836.
40. Meltzer MC, Desmond RA, Schwebke JR. Association of Mobiluncus curtisii with recurrence of bacterial vaginosis. Sex Transm Dis. 2008;35:611-613.

41. Marrazzo JM, Thomas KK, Fiedler TL, Ringwood K, Fredricks DN. Relationship of specific vaginal bacteria and bacterial vaginosis treatment failure in women who have sex with women. Ann Intern Med. 2008;149:20-28

42. United Kingdom National Guideline for the management of bacterial vaginosis 2006. Available from http://www.bashh.org/ documents/62/62.pdf.

43. Australasian College of Sexual Health Physicians: Clinical Guidelines for the management of sexually transmissible infections among priority populations 2004. Available from http://www.wsahs.nsw. gov.au/services/sexualhealth/documents/STI_Management_Priority_ Populations_000.pdf.

44. Sherrard J. European Guideline for the management of vaginal discharge. Int J STD AIDS. 2001;12(supp1 3):73-77.

45. World Health Organisation. Guidelines for the Management of Sexually Transmitted Infections. 2003.

46. Canadian Guidelines on Sexually Transmitted Infections. Ottawa, ON: Public Health Agency of Canada. [Revised January 2008] Available from http://www.phac-aspc.gc.ca/std-mts/sti_2006/pdf/408_ Vaginal_Discharge.pdf.

47. Apte VV, Packard RS. Tinidazole in the treatment of trichomoniasis, giardiasis and amoebiasis. Report of a multicentre study. Drugs. 1978;15 Suppl 1:43-48.

48. Bashki JS, Ghiara JM, Nanivadekar AS. How does tinidazole compare with metronidazole? A summary report of Indian trials in amoebiasis and giardiasis. Drugs. 1978;15(suppl 1):33-42.

49. British National Formulary (BNF) 57. March 2009. Available from http://www.bnf.org/bnf/bnf/current/.
International Journal of Women's Health

\section{Publish your work in this journal}

The International Journal of Women's Health is an international, peerreviewed open-access journal publishing original research, reports, reviews and commentaries on all aspects of women's healthcare including gynaecology, obstetrics, and breast cancer. Subject areas include: Chronic conditions (migraine headaches, arthritis, osteoporosis);

\section{Dovepress}

Endocrine and autoimmune syndromes; Sexual and reproductive health; Psychological and psychosocial conditions. The manuscript management system is completely online and includes a very quick and fair peer-review system. Visit http://www.dovepress.com/ testimonials.php to read real quotes from published authors. 